\title{
ガラス温室におけるシンビジウム黄斑病菌のナタネ油粕施用用土での 分生子形成と飛散
}

\author{
市川 和規 $1^{*}$. 宮下 享子 $1,2 \cdot$ 斎藤 英毅 ${ }^{3}$
}

\begin{abstract}
ICHIKAWA, K. ${ }^{1 *}$, MIYASHITA, K. ${ }^{2}$ and SAITO, H. ${ }^{3}$ (2003). Production and dispersal of conidia of Fusarium spp., pathogens causing cymbidium yellow spot in the greenhouse, on rape seed oilcake. Jpn. J. Phytopathol. 69: 229-232.

Pathogens causing cymbidium yellow spot produced conidia on rape seed oilcake used as fertilizer. These conidia, as well as those produced on lesions of leaves, were the inoculation source. When plants with lesions were sprinkled with water, the pathogens increased a hundredfold on rape seed oilcake. Both types of conidia were dispersed in the wind by mist from a wind tunnel. Greenhouse experiments revealed that watering from the top of the plants also promoted fungal dispersal.
\end{abstract}

(Received October 4, 2002; Accepted March 12, 2003)

Key words: infection source, conidium dispersal, cymbidium yellow spot, Fusarium spp.

シンビジウム黄斑病（Cymbidium yellow spot）は葉に 発生し, Fusarium proliferatum race $\mathrm{Y}$ や Fusarium fractiflexum によって生じる黄斑病徵と Fusarium proliferatum race Bによって生じる黒斑病徵がある（Aoki et al., 2001; Ichikawa and Aoki, 2000). 本病の発生は, ガラス温室内 の温度が上がり灌水量が増える 4 月から10月頃にかけて増 加する. 本病に対しては有効な薬剂がない（市川ほか, 1997）ために有用微生物を利用した生物防除法（市川, 2002）が開発されつつあるが，実用化には至っていない. また，本病の伝染経路についても不明な点が多く，防除対 策に苦慮しているのが現状である. 今回, 栽培資材等の非 宿主上に形成される分生子が，伝染源となる可能性につい て検討するとともに, 本菌の分生子飛散方法について調査 を行い，いくつかの知見が得られたので報告する.

伝染源 葉の病斑上に形成される分生子の形成量につい ては，ほぼ連日行われる灌水との関係から調査した。病原 菌を接種して 2 か月間経過した罹病株を，20〜 $25^{\circ} \mathrm{C}$ のガ ラス温室内に置き, 灌水回数を 1 日に 1 回, 2 日に 1 回, 3 日に 1 回に変えた場合の病斑上に形成される分生子量を
調査した. 分生子量の計測は, 病斑を含む葉片を殺菌水で 洗浄し, PDA 培地を用いて希釈平板法によりコロニー数 を定量した。病原菌は黄斑系統菌として F. fractiflexum (92-17-3), 黒斑系統菌として F. proliferatum race B (9242-1）を用いた。調査病斑数は20個で, 試験は 2 反復とし た. その結果, 1 病斑当たりのコロニー数は, 黄斑打よび 黒斑ともに灌水間隔が増すにつれて増加したが，1 日当た りの換算値は, 数個〜10数個と少量であった（Table 1). 本病原菌が増殖可能な栽培資材としては, 用土として一般 的に用いられるバークと肥料であるナタネ油粕が考えられ る.そこで，バーク（パインバーク：GRO WELL MO2, Auckland）を詰めた $9 \mathrm{~cm}$ ポリポットに罹病苗を植え，そ の株元周囲にナタネ油粕（豊年菜種粕）あるいは化成肥料 $(\mathrm{N}: \mathrm{P}: \mathrm{K}=8: 8: 8)$ を鉢当たり $5 \mathrm{~g}$ 施用するか, もし くは無施用とした。罹病苗は黄斑系統菌 $F$. proliferatum race $\mathrm{Y}$ (92-14-1) と $F$. fractiflexum (92-17-3, 93-1-1) お よび黒斑系統菌 F. proliferatum race B (92-42-1，93-15-1, 95-87-1）をそれぞれ接種した発病苗を用いた。 その後, 病斑上の分生子をこれらの用土に接種するために葉上より

\footnotetext{
${ }^{1}$ 山梨県総合農業試験場（干407-0105 山梨県北巨摩郡双葉町下今井1100） Yamanashi Agriculture Research Center, Shimoimai, Futaba, kitakoma, Yamanashi 407-0105, Japan

2 現在 : 山梨県果樹試験場（干405-0043 山梨県山梨市江増原1204） Yamanashi Fruit Tree Experiment Station, Ezohara, Enzan, Yamanashi 405-0043, Japan

3 信州大学䋊維学部（采386-8567 長野県上田市常田 3 丁目15番 1 号） Experimental Farm Attached to Fuculity of Textile Science and Technology, Shinshu University, Tokita, Ueda, Nagano 386-8567, Japan

* Corresponding author (E-mail: kazunori@comlink.ne.jp)
} 
Table 1. Number of propagules produced on a lesion of cymbidium yellow spot at different intervals of water sprinklinga)

\begin{tabular}{lccc}
\hline Pathogens causing & \multicolumn{3}{c}{ Interval of water sprinkling (day) } \\
cymbidium yellow spot & 0 & 1 & 2 \\
\hline Yellow spot pathogen & & & \\
$\quad$ Fusarium fractiflexum & & & \\
& $4.8 \pm 2.0$ & $3.7 \times 10 \pm 7.9$ & $4.8 \times 10 \pm 7.1$ \\
& $(4.8 \pm 2.0)$ d) & $(1.9 \times 10 \pm 4.0)$ & $(1.6 \times 10 \pm 2.4)$ \\
Black spot pathogen & & & \\
Fusarium proliferatum race Bc) & $9.6 \pm 3.6$ & $1.4 \times 10 \pm 2.4$ & $5.2 \times 10 \pm 6.9$ \\
& $(9.6 \pm 3.6)$ & $(7.2 \pm 1.2)$ & $(1.7 \times 10 \pm 2.3)$ \\
\hline
\end{tabular}

a) Data indicate the number of colonies produced on PDA plates. Twenty lesions were sampled for each treatment.

b) Strain 92-17-3.

c) Strain $92-42-1$.

d) Value in parentheses is the number of colonies produced in 1 day. Mean value \pm standard error, based on two examinations per mean.

用土が十分にぬれるまで殺菌水を噴霧し，ガラス温室内で 通常管理した。処理 5 日，20日後に駒田培地（駒田，1976） を用いて希积平板法により定量し，各用土に抢ける本病原 菌の増殖状況について調査した，対照には健全苗を用い， 試験は 3 反復とした。その結果，罹病株が植えられたナタ ネ油粕施用用土では，いずれの場合にもコロニーが形成さ れ，その数は処理 20 日後において乾用土 $1 \mathrm{~g}$ 当たり 2.4 $3.2 \times 10^{3}$ 個であった（Table 2). なお，処理 5 日後ではコ ロニーの形成は認められなかった。 また，ナタネ油粕施用 用土で増殖した菌の病原性を確認するため，処理20日後の
同用土に殺菌水を加え， 2 重ガーゼでろ過したろ液をシン ビジウムに噴霧接種した。接種条件は $26^{\circ} \mathrm{C}$, RH $100 \%$, 3 日間とし, 以後通常に管理後, 接種 40 日後に発病状況を 調べた．その結果，シンビジウムには，苗接種菌特有の病 徵が認められた（Table 2).

風洞試験による分生子飛散 シンビジウム栽培における 灌水は，夏季や秋季の晴天日には 1 日に 1 回，夏季には鉢 温度を下げるために 1 日に $2 \sim 3$ 回，株上から行われる. また，ガラス温室内は温度管理とシンビジウムの生育管理 上の点から常に送風されている．本菌の分生子の飛散は,

Table 2. Number of propagules produced on the potting media in pots with diseased cymbidium plants and pathogenicity of the propagules ${ }^{\mathrm{a}}$

\begin{tabular}{|c|c|c|c|c|}
\hline \multirow[b]{2}{*}{ Plants inoculated with } & \multicolumn{4}{|c|}{ Potting media } \\
\hline & Bark chip & $\begin{array}{l}\text { Bark chip and } \\
\text { chemical fertilizer }\end{array}$ & $\begin{array}{l}\text { Bark chip and } \\
\text { rape seed oilcake }\end{array}$ & Pathogenicity \\
\hline \multicolumn{5}{|l|}{ Yellow spot pathogens } \\
\hline$F$. proliferatum race $\mathrm{Y}^{\mathrm{b})}$ & 0 & 0 & $\left.2.9 \times 10^{3} \pm 3.0 \times 10^{2} \mathrm{~h}\right)$ & $\mathrm{Y}$ \\
\hline F. flactiflexum ${ }^{\mathrm{c})}$ & 0 & 0 & $3.0 \times 10^{3} \pm 2.0 \times 10^{2}$ & $\mathrm{Y}$ \\
\hline F. flactiflexum ${ }^{\mathrm{d})}$ & 0 & 0 & $2.4 \times 10^{3} \pm 2.0 \times 10^{2}$ & $\mathrm{Y}$ \\
\hline \multicolumn{5}{|l|}{ Black spot pathogens } \\
\hline$F$. proliferatum race $\mathrm{B}^{\mathrm{e})}$ & 0 & 0 & $3.2 \times 10^{3} \pm 5.0 \times 10^{2}$ & $\mathrm{~B}$ \\
\hline$F$. proliferatum race $\mathrm{B}^{\mathrm{f})}$ & 0 & 0 & $2.4 \times 10^{3} \pm 2.0 \times 10^{2}$ & $\mathrm{~B}$ \\
\hline$F$. proliferatum race $\mathrm{B}^{\mathrm{g})}$ & 0 & 0 & $2.4 \times 10^{3} \pm 2.0 \times 10^{2}$ & $\mathrm{~B}$ \\
\hline No treatment & 0 & 0 & 0 & - \\
\hline
\end{tabular}

a) Figures indicate the number of colonies per $g$ dry potting medium produced on Komada's medium 20 days after inoculation. Tree pots were determined for each treatment.

b) Strain $92-14-1$

c) Strain $92-17-3$.

d) Strain 93-1-1.

e) Strain $92-42-1$

f) Strain 93-15-1.

g) Strain 95-87-1.

h) Mean value \pm standard error, based on three examinations per mean. 
こうした灌水や送風によって起こっている可能性が考えら れたので, 風洞試験によって検討した. 風洞は, アクリル 製直方体（通風面：縦 $45 \times$ 横 $40 \times$ 長さ $100 \mathrm{~cm}$ ）で, 平行 格子が付いたものを使用した。 伝染源は PDA 平板培地で 培養された菌叢上や罹病株の病斑上およびナタネ油粕上に 形成させた分生子を用いた。風洞は換気扇から $24 \mathrm{~cm}$ 離 して設置し風洞の風の取り入れ口から $70 \mathrm{~cm}$ のところに 伝染源を置いた.PDA 培養面では風速 $1.0 \mathrm{~m} /$ 秒と $3.0 \mathrm{~m}$ /秒の送風をした場合および送風と同時に風の取り入れ口 から水 (360 ml/分) を噴霧した場合の 2 通りの処理を行 い, 病斑および油粕では送風と同時に水を噴霧した。 $\mathrm{PDA}$ 培地の場合は, 各供試菌を平板培地で $25^{\circ} \mathrm{C}, 3$ 週間 培養後, 大きさ $25 \mathrm{~mm} \times 20 \mathrm{~mm}$ の菌叢上に分生子を形成 させ, 風洞内に入れた. 病斑の場合は, 黄斑系統菌を感受 性品種「ラブリーバニー ‘ロミオ’」に, 黒斑系統菌を感 受性品種の「ラブリーエンジェル ‘ザ ッーバージンズ’」 にそれぞれ噴霧接種し, 接種 90 日後の罹病株を用いた。す なわち, 病斑を水洗後, 恒温器内で $25^{\circ} \mathrm{C}, \mathrm{RH} 100 \%, 3$
日間静置して分生子を形成させ，罹病株ごと風洞内に入れ た. 油粕の場合は, 表面殺菌した径 $6 \mathrm{~cm}$ のポリポットに クロルピクリンによりくん蒸消毒したバークをドーム状に 盛り上がるように詰め, その上に油粕を $3 \mathrm{~g}$ 施用し, 供試 菌を接種した。 $25^{\circ} \mathrm{C}$, $\mathrm{RH} 80 \%$, 自然日長下で 10 日間培養 して分生子を形成させ，ポットごと風洞内に入れた。供試 菌は, 黄斑系統菌として F. proliferatum race $\mathrm{Y}$ (92-14-1) と F. fractiflexum (93-1-1), 黒斑系統菌として F. proliferatum race B（94-42-1，95-87-1）を用いた. 分生子の捕捉は, 伝 染源から $10 \mathrm{~cm}$ 離れたところに捕捉台を設置し, 底面か ら 7，12，17，22，27，32，37 cm の 7 段階の高さにグリ セリンジェリーを塗ったスライドグラスを風の進行方向に 対し $30^{\circ}$ の角度で配置した. $18 \mathrm{~mm}$ 四方の分生子を計数 し, これを合計して捕捉数とした. 伝染源の高さは, 風洞 底面から PDA 培地では培地表面を $20 \mathrm{~cm}$, 罹病株では病 斑の位置を約 25〜 30 cm, 油粕では施用位置を $15 \mathrm{~cm}$ とし た. 捕捉時間はPDA 培地では 8 秒間, 病斑と油粕では 16 秒間で, 試験は 3 反復とした. その結果, PDA 培地上に

Table 3. Dispersal of conidia of Fusarium spp. produced on PDA plates in a wind tunnel ${ }^{\text {a) }}$

\begin{tabular}{|c|c|c|c|c|}
\hline \multirow{2}{*}{$\begin{array}{l}\text { Pathogens causing } \\
\text { cymbidium yellow spot }\end{array}$} & \multicolumn{2}{|c|}{ Wind } & \multicolumn{2}{|c|}{ Wind and Mist ${ }^{\mathrm{a}}$ ) } \\
\hline & $1.0 \mathrm{~m} / \mathrm{sec}$ & $3.0 \mathrm{~m} / \mathrm{sec}$ & $1.0 \mathrm{~m} / \mathrm{sec}$ & $3.0 \mathrm{~m} / \mathrm{sec}$ \\
\hline \multicolumn{5}{|l|}{ Yellow spot pathogens } \\
\hline$F$. proliferatum race $\left.\mathrm{Y}^{\mathrm{b}}\right)$ & 0 & 0 & $4.0 \times 10^{-1} \pm 3.0 \times 10^{-1 \mathrm{f})}$ & $9.1 \pm 5.7$ \\
\hline$F$. flactiflexum ${ }^{\mathrm{c})}$ & 0 & 0 & $3.0 \times 10^{-1} \pm 2.0 \times 10^{-1}$ & $9.0 \times 10^{-1} \pm 1.0 \times 10^{-1}$ \\
\hline \multicolumn{5}{|l|}{ Black spot pathogens } \\
\hline$F$. proliferatum race $\mathrm{B}^{\mathrm{d})}$ & 0 & 0 & $4.0 \times 10^{-1} \pm 3.0 \times 10^{-1}$ & $3.1 \times 10 \pm 1.2 \times 10$ \\
\hline$F$. proliferatum race $\mathrm{B}^{\mathrm{e})}$ & 0 & 0 & $4.0 \times 10^{-1} \pm 3.0 \times 10^{-1}$ & $8.9 \pm 2.0$ \\
\hline
\end{tabular}

a) Conidia were trapped in glycerin jelly $(18 \times 18 \mathrm{~mm})$ spread on glass slide exposed for $8 \mathrm{sec}$ in the wind with or without mist. Glass slide was placed $20 \mathrm{~cm}$ above and $10 \mathrm{~cm}$ away from the fungal culture.

b) Strain $92-14-1$.

c) Strain $93-1-1$.

d) Strain 92-42-1.

e) Strain 95-87-1.

f) No. of conidia trapped. Mean value \pm standard error, based on three examinations per mean.

Table 4. Dispersal of conidia of Fusarium spp. produced on diseased cymbidium plants or on infested rape seed oilcake in a wind tunnela ${ }^{\text {a }}$

\begin{tabular}{lcc}
\hline $\begin{array}{l}\text { Pathogens causing } \\
\text { cymbidium yellow spot }\end{array}$ & Diseased plant & Rape seed oilcake \\
\hline $\begin{array}{l}\text { Yellow spot pathogen } \\
\text { F. proliferatum race } \mathrm{Y}^{\mathrm{b})}\end{array}$ & $1.3 \times 10^{2} \pm 8.0 \times 10^{\mathrm{d})}$ & $2.1 \times 10^{4} \pm 1.0 \times 10^{4}$ \\
$\begin{array}{l}\text { Black spot pathogen } \\
\text { F. proliferatum } \text { race } \mathrm{B}^{\mathrm{c})}\end{array}$ & $3.2 \times 10^{2} \pm 1.8 \times 10^{2}$ & $1.0 \times 10^{4} \pm 5.0 \times 10^{3}$ \\
\hline
\end{tabular}

a) See Table 3. Exposure time was $16 \mathrm{sec}$ and wind velocity was $1.0 \mathrm{~m} / \mathrm{sec}$ in the wind with mist.

b) Strain $92-14-1$.

c) Strain $92-42-1$.

d) Total number of conidia trapped in $18 \times 18 \mathrm{~mm}$ square. Each slide was placed 7, 12, 17, 22, 27, 32 and $37 \mathrm{~cm}$ above. Mean value \pm standard error, based on three examinations per mean. 
形成させた分生子の飛散は風速 $3.0 \mathrm{~m} /$ 秒以下の送風のみ では認められなかったが，水滴を伴った場合には風速 $1.0 \mathrm{~m} /$ 秒でも認められた（Table 3). 罹病株の病斑上やナ タネ油粕上に形成させた分生子も, 水滴を伴った風速 $1.0 \mathrm{~m} /$ 秒の送風で飛散が認められた (Table 4). な拉, 分 生子は伝染源々同程度かそれ以下の高さから捕捉された が，伝染源より高い位置では捕捉されなかった。

病気の伝播 PDA 培地上, 病斑上およびナタネ油粕上 に形成された分生子は，送風だけでは飛散しないが，水滴 を伴うと風速 $1.0 \mathrm{~m} /$ 秒の微風でも飛散が認められた。 こで, ガラス温室内で 9 月 26 日から 12 月 11 日まで栽培試験 を行い, 灌水時の送風の有無が本病の伝播に及ぼす影響に ついて検討した。試験区は, 黒斑系統菌に感受性の品種 「ラブリーエンジェル ‘ザ ツーバージンズ’」の $9 \mathrm{~cm}$ 鉢 植え一年生苗144株を, 鉢間隔 $8 \times 10 \mathrm{~cm}, 24$ 列 6 条に配置 した。ほぼ中央に黒斑のある罹病株を伝染源として 3 株ず つ設置したものを二組用意した。一方は, 風速 $3.0 \mathrm{~m} /$ 秒 の送風を20分間行った後, 株上からミスト灌水を 20 分間行 い，他方はミスト灌水と送風を同時に20分間行った。な お, 各試験区は， $5 \mathrm{~m}$ 離して設置した。送風抢よび灌水は 試験期間を通して午前 9 時前後に行った. また, 送風は列 側からとした．施肥は，ナタネ油粕を試験開始時および 34 日後に鉢当たり $3 \mathrm{~g}$ を株元に施用した. 試験開始から76日 後に各鉢における発病状況を調査した。 その結果, 送風停 止直後に株上からミスト灌水をした場合は，伝染源である 罹病株の周囲約 $30 \mathrm{~cm}$ 以内で 16 株が発病した。これに対 してミスト灌水と送風を同時に処理した場合は, 罹病株の 周囲約 $30 \mathrm{~cm}$ 以内で 8 株が発病したばかりでなく, 罹病 株の風下約 $60 \sim 100 \mathrm{~cm}$ 離れた場所でも 8 株が発病した. 飛散範囲に違いはあるものの発病株が同じであることか ら, 灌水時に送風が無くても菌が飛散することが考えられ た. 黄斑病徵を示す罹病株を用いた試験においても黒斑罹 病株の試験と同様であった.

シンビジウム黄斑病菌は, 菌の形態的特徵, 分子系統学 的分類および病原性の違いから F. fractiflexum (Aoki et al., 2001), F. proliferatum race $\mathrm{Y}$ および F. proliferatum race B (Ichikawa and Aoki, 2000; Nirenberg and O'Donnell, 1998）と同定された新種と新レースであるため, 生態学的 な報告は現在のところ知られていない. 本病の伝染につい ては, 病斑とともに肥料であるナタネ油粕で増殖した黄斑 病菌が重要な伝染源になっているものと考えられた. 本菌 は風を伴わない水滴の落下, 頭上灌水によっても罹病株の 周囲に飛散し, 灌水時の送風は菌の拡散を助長しているも
のと考えられた。イネばか苗病菌 (Fusarium moniliforme) における送風試験では, 分生子の飛散は送風のみでは風速 の強弱によらず起こらなかったとの報告（渡部，1985）と 風速が強くなると多くなったとの報告（鈴木，1976）があ るが, 両報告とも水滴を伴う送風では多量の分生子が飛散 したと報告（鈴木, 1976; 渡部, 1985）されている. 围場試 験では, 降雨が分生子の飛散を助長し（佐々木, 1987), 多量の分生子が雨水中から採種されたとの報告（鈴木, 1976）がある．また，トウモロコシ赤かび病菌（Fusarium moniliforme）の発生戋場でも降雨の飛沫水の中から分生 子が採種された（Ooka and Kommedahl, 1977）との報告 がある.これらの報告は F. moniliforme 分生子の飛散要因 として風よりもむしろ水滴の存在を強く裏付けているよう に思われる. シンビジウム栽培では, 夏季にはナタネ油粕 の施肥量が増えることにより本菌の菌密度が高まり, 灌水 量と灌水回数の増加により飛散回数の機会が増えるものと 考えられる。このことが, 夏季に本病の発生が多くなる発 生推移と関連しているものと推察される. このように本病 の発生は慣行の栽培様式に根ざしたものであると考えられ る.

\section{引用文献}

Aoki, T., O'Donnell, K. and Ichikawa, K. (2001). Fusarium fractiflexum sp. nov. and two other species within the Gibberella fujikuroi species complex recently discovered in Japan that form aerial conidia in false heads. Mycoscience 42: 461-478.

市川和規・舟久保太一・村上芳照 (1997)。 シンビジウム黄斑 病に対する有効薬剂の検索. 関東病虫研報 44: 187-189.

Ichikawa, K. and Aoki T. (2000). New leaf spot disease of Cymbidium species caused by Fusarium subglutinans and Fusarium proliferatum. J. Gen. Plant Pathol. 66: 213-218.

市川和規 (2002). 弱病原力 Fusarium sp. HPF-1 株によるシン ビジウム黄斑病の生物防除. 日植病報 68: 21-27.

駒田 旦(1976). 野菜のフザリウム病菌, Fusarium oxysporum, の土壌中における活性評価技術に関する研究. 東海近畿 農試研報 29: 132-269.

Nirenberg, H.I. and O'Donnell, K. (1998). New Fusarium species and combinations within the Gibberella fujikuroi species complex. Mycologia 90: 434-458.

Ooka, J.J. and Kommedahl T. (1977). Window and rain dispersal of Fusarium moniliforme in corn fields. Phytopathology 67: 1023-1036.

佐々木次雄 (1987). イネばか苗病の発生生態と防除に関する 研究. 東北農試研報 74: 1-47.

鈴木穂積 (1976). 稲馬鹿苗病菌はどのようにして種モミにつ くようになるか. 今月の農薬 20(3): 71-74.

渡部 茂 (1985). イネ馬鹿苗病の発生生態並びにその防除技 術の改善に関する研究. 岩手農試研報 25: 1-73. 